\title{
1982 ANAYASASINA GÖRE YASAMA ORGANI ÜYE SAYISI VE YASAMA ORGANI ÜYE SAYISINDA MEYDANA GELEN DEĞİŞIKLIKLER
}

IN RELATION TO THE 1982 CONSTITUTION THE NUMBER OF MEMBERS OF LEGISLATIVE

BODY AND ITS AMENDMENTS

Hakemli Makale

İbrahim YILMAZ*

\section{İÇiNDEKILER}

GíRIS 934

I. 1982 ANAYASASINA GÖRE YASAMA ORGANI ÜYE SAYISI VE DEĞIŞSIKLIKLERİ 937

A. Genel Olarak Yasama Organı Üye Sayısı 937

B. Türkiye'de Anayasalar ve Yasama Organı Üye Sayısı 938

C. 1982 Anayasasına göre Milletvekilliği Sayısında Meydana Gelen Değişlikler ve Gerekçeleri .......940

II. TÜRKIYE ve OECD ÜLKELERI MILLET MECLISİ ÜYE SAYILARI: KÜPKÖK YASASI .........995

A. OECD Ülkeleri Millet Meclisi Üye Sayıları: 1969-2019 ................................................................ 945

B. OECD Ülkeleri ve Küpkök Yasası ............................................................................................ 949

III. MILLLETVEKILİ SAYISININ DEĞIŞMESININN SEÇIM ÇEVRELERİNE ETKİSİ ........................ 951

SONUÇ 955

DOI: $10.32957 /$ hacettepehdf.892169

* Dr. Öğr. Üyesi, Samsun Üniversitesi, İktisadi, İdari ve Sosyal Bilimler Fakültesi, Siyaset Bilimi ve Kamu Yönetimi Bölümü, E-posta: ibrahim.yilmaz@ samsun.edu.tr Çalışmamda Araştırma ve Yayın Etiği İlkeleri’ne uyulduğunu beyan ederim. ORCID: 0000-0002-6081-6648 


\title{
ÖZ
}

1982 Anayasasının Türkiye Büyük Millet Meclisi üye sayısı hakkında hüküm içeren 75. maddesi, 16 Nisan 2017 tarihinde kabul edilen Anayasa değişikliği referandumu ile birlikte üçüncü kez değiştirilmiş oldu. Bu çalışma, 1982 Anayasasının yasama organı üye sayısını belirleyen 75. maddesinin değiştirilişini üç temel konu başlığı altında ele almaktadır. İlk olarak, Türkiye'de yasama organı üye sayısı değişiklikleri, anayasa değişikliği teklifi kanununun madde gerekçeleri, Anayasa Komisyonu Raporları ve Türkiye Büyük Millet Meclisi Genel Kurul görüşmeleri 1şı̆̆ında değerlendirilmektedir. İkinci olarak, Türkiye'deki yasama organı üye sayısı diğer OECD ülkelerinin yasama organı üye sayıları ile küpkök yasası dikkate alınarak mukayese edilmektedir. Son olarak, milletvekili sayısının 550'den 600'e çıkarılmasının seçim çevrelerine etkileri üzerinde durulmaktadır.

Anahtar Kelimeler: Milletvekili sayısı, 1982 Anayasasının 75. maddesi, OECD ülkeleri millet meclisi üye sayısı, anayasa değişikliği, küpkök yasası.

\begin{abstract}
With the approval of the constitutional referandum held on 16 April 2017, the 75th article of the 1982 Constitution which rules the members of the Grand National Assembly of Turkey, has been amended for the third time. This study discusses the amendments of 75 th article of the 1982 Constitution which determines the number of members of legislative body under three chapters. First of all, increase of the number of members of legislative body in Turkey is evaluated regarding the article's preamble, Report of Constitution Committe and discussion held in General Assembly. Secondly, the number of members of legislative body in Turkey is compared with the OECD countries in relation to the cube-root rule. Lastly, the impact of increase in the number of members of parliament from 550 to 600 on electoral districts is elaborated.
\end{abstract}

Keywords: Number of members of parliament, the 75th Article of the 1982 Constitution, number of members of representative house of OECD countries, constitutional Amandment, cube-root rule. 


\section{GíRiș}

Egemenliğin kullanılması bakımından demokrasi, genel olarak doğrudan demokrasi, yarı-doğrudan demokrasi ve temsili demokrasi olmak üzere üçe ${ }^{1}$ ayrılmaktadır $^{2}$. Günümüzde demokrasi ile yönetilen devletlerin hemen hemen hepsinin yönetim anlayışı ya temsili demokrasiye ya da yarı doğrudan demokrasiye dayanmaktadır. Temsili demokrasi kısaca "halkın egemenliğini kendi seçtiği temsilcileri aracılığıyla kullandığı demokrasi tipi"” yarı doğrudan demokrasi ise "egemenliğin kullanılmasının halk ile temsilcileri arasında paylaştırıldı $\breve{g}_{1}$ demokrasi tipi”4 ${ }^{4}$ olarak tanımlanabilir. Her iki durumda da halkın belirlemiş olduğu temsilciler belirli bir süre boyunca (genel olarak 4 ya da 5 yıl) ${ }^{5}$ yasama organı üyesi olarak görev yapmaktadır. Yasama organı tek meclis ya da çift meclisli ${ }^{6}$ bir yapıda olabilmektedir ${ }^{7}$. Federal devletler açısından yasama organının çift meclisli olmasının bir zorunluluk olduğu ifade

1 İBA, Şeref., Anayasa Hukuku Genel Esaslar, 3. Basım, Turhan Kitabevi Yayınları, Ankara, 2017, s. 119-128; GÖZLER, Kemal., Anayasa Hukukunun Genel Esasları Ders Kitabı, 11. Basım, Ekin Basım Yayın Dağıtım, Bursa, 2019, s. 273-297.; ANAYURT, Ömer., Anayasa Hukuku Genel Kısım (Temel İlkeler, Kavram ve Kurumlar), 2. Basım, Seçkin Akademik ve Mesleki Yayınlar, Ankara, 2019, s.457-480.

2 Egemenliğin kullanılmasına göre yönetim biçimlerinin sınıflandırılmasında dörtlü bir ayrıma da gidilmektedir. Bu sınıflandırmaya göre, egemenliğin kullanılmasına göre yönetim biçimleri, temsili hükümet, yar1-temsili hükümet, yarı-doğrudan hükümet ve doğrudan hükümet olarak dörde ayrılmaktadır. Bu konu hakkında daha detaylı bilgi için bknz FENDOĞLU, Hasan Tahsin., Anayasa Hukuku, 7. Basım, Yetkin Yayınları, Ankara, 2019, s.335.; TEZŻÇ, Erdoğan., Anayasa Hukuku, 23. Basım, Beta Basım Yayım Dağıtım, İstanbul, 2019, s. 279.

3 GÖZLER, 2019, s. 278.

4 GÖZLER, 2019, s. 289.

5 Arend Liphart, parlamenter sisteme sahip demokratik ülkelerin yasama meclisi üyeliği süresinin tek meclisli yasama organına sahip olanlar ile iki meclisli yasama organına sahip olanların alt meclisinde en fazla 4 ya da 5 yil olduğunu bununla beraber, Avusturalya ve Yeni Zelanda gibi 3 yıl olan ülkelerin de bulunduğunu belirtmektedir, bakınız. LIJPHART, Arend, "Reforming the House: Three Moderately Radical Proposalss", PS: Political Science and Politics, Y11: 1998, Cilt: 31, Sayı: 1, (s. 12). Günümüzde olağan yasama dönemi; Türkiye'de ve İtalya'da (yasama organının alt meclisi Milletvekili Meclisi için) 5 yıl, Yunanistan'da ve İspanya'da (yasama organının alt meclisi Kongre için) 4 yıl ve Amerika Birleşik Devletleri'nde (ABD) (yasama organının alt meclisi olan Temsilciler Meclisi için) 2 yıldır.

6 Çift meclisli yapının kökeni için bakınız, COAKLEY, John, "The Strange Revival of Bicameralism", The Journal of Legislative Studies, Y11: 2014, Cilt: 20, Say1: 4, (s. 543-7).

7 KABOĞLU, İbrahim Ö., Anayasa Hukuku Dersleri (Genel Esaslar), 14. Basım, Legal Yayıncılık, İstanbul, 2019, s. 112.; TEZİÇ, Erdoğan., Anayasa Hukuku, 23. Basım, Beta Basım Yayım Dağıtım, İstanbul, 2019, s. 441. 
edilmektedir ${ }^{8}$. Federal devletlerde yasama organı genellikle millet meclisi ve senato olarak ikiye ayrılmakta, ilki federal devletin halkını temsil etmekte iken ikincisi ise federasyonda yer alan birimleri temsil etmektedir ${ }^{9}$. Üniter devletler açısından ise yasama organı tek meclisli olabileceği gibi çift meclisli de olabilir. Günümüzde üniter devletlerin çoğu tek meclisli bir yapıyı benimserken ${ }^{10}$, Fransa ve İtalya gibi çift meclisli yapıyı benimseyen üniter devletler de mevcuttur.

Temsili demokrasi ya da yarı doğrudan demokrasi anlayışını benimseyen ülkelerde egemenlik halkın belirlediği temsilciler aracılığı ile kullanıldığı için bu ülkelerin en önemli kurumlarından biri hiç şüphesiz yasama organı olmaktadır. Yasama organı üyelerinin nasıl belirleneceği (seçim sistemi), yasama organı üyelerinin hangi kriterlere sahip olması gerektiği, yasama organının büyüklüğünün ne olması gerektiği gibi konular temsili demokrasi ve yarı doğrudan demokrasi anlayışını benimsemiş ülkelerde hala zaman zaman tartışma konusu olmakta ve bu konularla ilgili olarak hukuksal değişikliklere gidilmektedir.

Yasama organı üyelerinin belirlenme şekli (seçim sistemleri) ve bunun etkileri hem uluslararası hem de ulusal alan yazınında ${ }^{11}$ oldukça çalışılan bir konu başlığı olmakla beraber, yasama organı üye sayısı ve değişikliği hakkında hem uluslararası hem de ulusal alan yazınında oldukça sınırlı sayıda çalışma yer almaktadır ${ }^{12}$. Bu çalışma bir nebze de olsa yasama organı üye sayısı ile ilgili alan yazınına katkı sunmayı amaçlamaktadır.

8 FENDOĞLU, Hasan Tahsin., Anayasa Hukuku, 7. Basım, Yetkin Yayınları, Ankara, 2019, s.433.; KABOĞLU, 2019, s. 112.; TEZİÇ, 2019, s. 441.

9 KABOĞLU, 2019, s. 113.; TEZİÇ, 2019, s. 441.

10 Günümüzde devletlerin meclis yapıları için bakınız, IPU PARLINE, Global Data on National Parliaments, https://data.ipu.org/elections, (erişim tarihi: 17.02.2021).

11 ÖZBUDUN, Ergun, "Seçim Sistemleri ve Türkiye", Ankara Üniversitesi Hukuk Fakültesi Dergisi, Y1l: 1995, Cilt: 44, Say1: 1 (s. 521-539).; OLGUN, Kenan, “Türkiye'de Cumhuriyetin İlanından 1950’ye Genel Seçim Uygulamaları”, Atatürk Araştırma Merkezi Dergisi, Y11: 2011, Cilt: 27, Say1: 79, (s. 136).; NIŞANCI, Şükrü / ÖZDEMİR, Abdulkadir, "Dünyada Uygulanan Seçim Sistemleri Işığında Türkiye için Alternatif Seçim Önerileri”, Atatürk Üniversitesi Sosyal Bilimler Enstitüsü Dergisi, Y1l: 2017, Cilt: 21, Say1: 2, (s. 723-745).

12 Diğer ülkelerde de yasama oranı büyüklüğünü belirleyen faktörlerin neler olduğunu ele alan çalışma sayısı oldukça sınırlıdır, bakınız JACOBS, Kristof / OTJES, Simon, "Explaining the Size of Assemblies. A Longitudinal Analysis of the Design and Reform of Assembly Size in Democracies around the World", Electoral Studies, Y1l: 2015, Cilt: 40, (s. 281). 
1982 Anayasasının en fazla değişikliğe uğrayan maddelerinden birisi Türkiye Büyük Millet Meclisi (TBMM) üye tamsayısını düzenleyen maddesidir. 1982 Anayasasının TBMM üye sayısını düzenleyen 75. maddesi, 16 Nisan 2017 Anayasa değişikliği referandumunun kabul edilmesiyle birlikte, yürürlüğe girdiği andan itibaren üçüncü kez değişikliğe uğradı. 1982 Anayasasının ilk halinde 400 olarak öngörülen TBMM üye sayısı 1987 yılında kabul edilen anayasa değişikliği ile 450'ye, 1995 yılında kabul edilen anayasa değişikliği ile 550'ye ve son olarak 2017 y1lında kabul edilen anayasa değişikliği ile 600'e çıkarıldı. Bu makale, 1982 Anayasasının yasama organı üye sayısını belirleyen 75. maddesinin değiştirilişini sırasıyla üç temel konu başlığı altında ele almaktadır. İlk olarak, Anayasa değişikliği teklifi ve kabul sürecine odaklanmaktadır. Bu bağlamda Türkiye'de yasama organı üye sayısı değişikliklerini, anayasa değişikliği teklifi kanunu madde gerekçeleri, TBMM Genel Kurulu'na sunulan Anayasa Komisyonu Raporları ve TBMM Genel Kurul görüşmeleri 1şığında değerlendirmektedir. İkinci olarak ise 16 Nisan 2017 tarihinde kabul edilen Anayasa değişikliği referandumu sonucu 600 olan TBMM üye sayısı, daha önceki çalışmalar referans alınarak, İktisadi İşbirliği ve Gelişme Teşkilatı (OECD) üyesi 36 ülke ile mukayese edilmektedir ${ }^{13}$. Bu doğrultuda, Türkiye'deki yasama organı üye sayısı OECD üyesi 36 ülke yasama organı üye sayıları ile küpkök yasası dikkate alınarak mukayese edilmektedir. Son olarak ise milletvekili sayısının 550'den 600'e çıkarılmasının Türkiye'de seçim çevrelerine etkileri üzerine durulmaktadir.

13 OECD ülkelerinin millet meclisi büyüklüklerinin küpkök yasası bağlamında mukayese edildiği diğer çalışmalar için bakınız. LADEWIG, Jeffrey W / JASINSKI Mathew P, "On the Causes and Consequences of and Remedies for Interstate Malapportionment of the U.S. House of Representatives" Perspectives on Politics, Y11: 2008: Cilt: 6, Say1: 1, (s. 99).; FREDERICK, Brian, Congressional Representation and Constituents. The Case for increasing the US House of Representatives, Rothledge, New York, 2010, s. 4. 


\section{1982 ANAYASASINA GÖRE YASAMA ORGANI ÜYE SAYISI VE DEĞİŞiKLIKLERİ}

\section{A. Genel Olarak Yasama Organı Üye Sayısı}

Ülkelerin yasama organı üye sayısının kaç olduğuna dair hüküm, genellikle o ülkenin anayasasında ya da ilgili kanunlarında yer almaktadır. Kimi ülkelerde ise her iki hukuk metninde de bu durum hakkında hüküm bulunmaktadır. Örneğin, günümüzde Türkiye'de milletvekili sayısı hem 1982 Anayasasında hem de 10/06/1983 tarih ve 2839 sayılı Milletvekili Seçimi Kanunu'nda düzenlenmiştir. Yasama organı üye sayısı hakkında Anayasalarında hüküm bulunan ülkelerin bir kısmında yasama organı üye sayısının üst limiti belirlenirken, bir kısmında hem alt hem üst limit belirlenmiş, bir kısmında ise bu sayı sabit bir sayı olarak tayin edilmiştir. Örneğin Danimarka ${ }^{14}$ ve Fransa $^{15}$ anayasalarında yasama organı üye sayısının üst limiti tayin edilirken, Yunanistan ${ }^{16}$ ve İspanya ${ }^{17}$ Anayasalarında ise hem alt hem de üst limit tayin edilmiştir.

14 Danimarka Anayasasının 28. maddesine göre Danimarka Krallı̆̆ı'nın tek meclisli yasama organı olan Folketing'in üye sayıs1 179'dan fazla olamaz. FOLKETINGET THE DANISH PARLIAMENT, The Constitutional Act of Denmark, https://www.thedanishparliament.dk/en/democracy/theconstitutional-act-of-denmark. (erişim tarihi: 25.01.2021).

15 Fransa Anayasasının 24. Maddesine göre, Fransa Parlamentosu, Ulusal Meclis ve Senatoyu içermektedir ve Ulusal Meclis üye sayısı 577'den fazla olamaz. CONSEIL CONSTITUTIONNEL, Constitution of 4 October 1958, https://www.conseil-constitutionnel.fr/en/constitution-of-4-october1958, (erişim tarihi: 25.01.2021).

16 Yunanistan Anayasasının 51. Maddesine göre Parlamento üye sayısı kanunla belirlenir fakat bu sayısı 200'den aşağı 300'den yukarı olamaz. HELLENIC PARLİAMENT, The Constitution of Greece, https://www.hellenicparliament.gr/en/Vouli-ton-Ellinon/To-Politevma/Syntagma/, (erişim tarihi: 7.02.2021).

17 İspanya Anayasasına göre İspanya'nın yasama organı olan Cortes Generales, Temsicliler Meclisi (Congress of Deputies) ve Senato isimli iki meclisten oluşmaktadır ve İspanya Anayasasının 68. maddesine göre Temsilciler Meclisi üye sayısı en az 300 en fazla 400 kişiden meydana gelir. SENADO DE ESPANA, Spanish Constitution, https://www.senado.es/web/conocersenado/normas/constitucion/detalleconstitucioncompleta/index.ht ml?lang=en (erişim tarihi: 21.01.2021). 
Diğer taraftan, Çek Cumhuriyeti ${ }^{18}$ ve Estonya ${ }^{19}$ anayasalarında ise yasama organı üye sayıları sabit bir sayı olarak belirlenmiştir. Bununla beraber, her anayasa yasama organı üye sayısı hakkında hüküm içermek gibi bir zorunluluğa sahip değildir.

\section{B. Türkiye'de Anayasalar ve Yasama Organı Üye Sayısı}

İlk Anayasamız olan 1876 Kânûn-i Esâsî’nin kabulünden günümüze beş farklı anayasanın uygulama alanı bulduğu ülkemizde, anayasaların üç tanesinde yasama organı üye sayısı hakkında hüküm yer almaktayken, iki anayasamızda ise bu konu hakkında açık bir hüküm bulunmamaktadır. 1876 Kânûn-i Esâsî, yasama organı üye sayısı hakkında hüküm içermekte fakat sabit bir sayı belirtmemektedir. Diğer taraftan, 1921 Anayasası (Teşkilâtı Esasiye Kanunu) ve 1924 Anayasasının (Teşkilâtı Esasiye Kanununda) ilk halinde ve sonradan eklenen ya da değiştirilen hallerinde de yasama organının üye sayısının ne olacağına dair açık bir hüküm yer almamaktadır. Türkiye'de yasama organı üye sayısını sabit bir sayı olarak belirleyen ilk anayasa 1961 Anayasasıdır ${ }^{20}$. 1982 Anayasası da bu anlayışı sürdürmüş ve yasama organı üye sayısını sabit bir sayı olarak tayin etmiştir.

Çift meclisin (Heyeti Mebusan ve Heyeti Âyan) öngörüldüğü 1876 Kânûn-i Esâsî’nin 60. maddesi Heyeti Âyan ve 65. maddesi ise Heyeti Mebusan üyelerinin sayıları hakkında hüküm içermektedir. 1876 Kânûn-i Esâsî’nin 65. maddesine ${ }^{21}$ göre Heyeti Mebusan, her elli bin erkek için bir meb’us (milletvekili) seçilerek meydana

18 Çek Cumhuriyeti Anayasası Millet Meclisi ve Senatodan oluşan iki meclisli bir yasama organı öngörmektedir ve Çek Cumhuriyeti Anayasasının 16. maddesine göre Millet Meclisi'nin milletvekili sayıs 200'dür. PARLIAMENT OF THE CZECH REPUBLIC CHAMBER OF DEPUTIES, Constitution of the Czech Republic, https://www.psp.cz/en/docs/laws/1993/1.html (erişim tarihi: 25.01.2021).

19 Estonya Cumhuriyeti Anayasasının 60. maddesine göre tek meclisli yasama organı olan Riigikogu'nun üye sayıs1 101'dir. RIIGI TEATAJA, The Constitution of the Republic of Estonia, RiigiTeataja, https://www.riigiteataja.ee/en/eli/521052015001/consolide (erişim tarihi: 25.01.2021).

20 ARMAĞAN, Servet, “Türkiyede Parlamento Seçimleri”, İstanbul Üniversitesi Hukuk Fakültesi Mecmuası, Y11: 1967, Cilt: 33, Sayı: 3-4, (s.97).

211876 Kânûn-i Esâsî, madde 65: "Heyeti Mebusanın mıktarı âzası tebaai Osmaniyeden her ellibin nüfus zükûrda bir nefer olmak itibariyle tertip olunur". TÜRKIYE CUMHURIYYTİ ANAYASA MAHKEMESİ (AYM), 1876 Kânûn-i Esâsî, https://www.anayasa.gov.tr/tr/mevzuat/oncekianayasalar/1876-k\%C3\%A2n\%C3\%BBn-i-es\%C3\%A2s\%C3\%AE/. (erişim tarihi: 25.01.2021). 
gelmektedir. 1876 Kânûn-i Esâsî'nin 60. maddesine ${ }^{22}$ göre ise Heyeti Âyan üyelerinin sayısı Heyeti Mebusan üyelerinin üçte birinden fazla olamaz. 1876 Kânûn-i Esâsî, her iki meclisin üye sayıları hakkında hüküm içermekte fakat bu meclislerin üye sayıları için her daim geçerli olacak sabit bir sayı öngörmemektedir. Diğer taraftan, 1921 Anayasası ve 1924 Anayasasının ilk halinde ve sonradan yapılan değişikliklerinde de yasama organının üye sayısının ne olacağına dair açık bir hüküm yer almamaktadır.

Yasama organı üye sayısını sabit bir sayı olarak öngören ilk anayasamız ${ }^{23} 1961$ Anayasası'dır ve bu yaklaşım 1982 Anayasasında da sürdürülmüştür. Çift meclisin (Millet Meclisi ve Cumhuriyet Senatosu) öngörüldüğ̈̈ 1961 Anayasasının 67. maddesi ${ }^{24}$ Millet Meclisi, 70. maddesi ${ }^{25}$ ise Cumhuriyet Senatosu üye sayısı hakkında hüküm içermektedir. Buna göre, Millet Meclisi için 450, Cumhuriyet Senatosu için ise genel oyla seçilen 150 üye sayısı tayin edilmiştir. 1961 Anayasası yürürlükte kaldığı süre boyunca, yasama organı üye sayısı hakkındaki hükümleri değişikliğe uğramamıştır.

Tek meclisli yasama organının öngörüldüğü 1982 Anayasasında, TBMM üye sayısı anayasanın 75. maddesinde düzenlenmiştir. Cumhuriyetin ilanından sonra, yasama organı üye sayısı hakkında hüküm içeren maddenin değişikliğe uğradığı ilk anayasa 1982 Anayasasıdır. 1982 Anayasası yürürlüğe girdiği andan bu yana, yasama organı üye sayısını düzenleyen 75. maddesi üç kez değişikliğe uğramıştır ${ }^{26} .1982$ Anayasasının ilk

221876 Kânûn-i Esâsî, madde 60: "Heyeti Âyanın reisi ve âzası nihayet miktarı Heyeti Mebusan âzasının sülüsü miktarını tecavüz etmemek üzere doğrudan doğruya tarafı hazreti padişahiden nasbolunur.”. TÜRKIYE CUMHURIYETİ ANAYASA MAHKEMESİ (AYM), (1876 Kânûn-i Esâsî).

23 ARMAĞAN, 1967, s. 97.

241961 Anayasası, madde 67: "Millet Meclisi, genel oyla seçilen dörtyüzelli milletvekilinden kuruludur”. TÜRKIYE CUMHURIYETİ ANAYASA MAHKEMESİ (AYM), (1961 Anayasası) https://www.anayasa.gov.tr/tr/mevzuat/onceki-anayasalar/1961-anayasasi/ (erişim tarihi: 25.01.2021).

251961 Anayasası, madde 70: “Cumhuriyet Senatosu, genel oyla seçilen yüzelli üye ile Cumhurbaşkanınca seçilen onbeş üyeden kuruludur. 13 Aralık 1960 tarihli ve 157 sayılı Kanunun altında adları bulunan Millî Birlik Komitesi Başkanı ve üyeleri ile eski Cumhurbaşkanları, yaş kaydı gözetilmeksizin, Cumhuriyet Senatosunun tabiî üyesidirler. Tabiî üyeler, Cumhuriyet Senatosunun diğer üyelerinin tâbi oldukları hükümlere tâbidirler. Ancak, Haklarında bu Anayasanın 73 üncü maddesinin 1 inci ve 2 nci fikraları ve 10 uncu geçici maddesinin 1 inci fikrası hükümleri uygulanmaz. Tabiî üye olarak Cumhuriyet Senatosuna katıldıktan sonra bir siyasî partiye girenlerin tabiî üyelik sıfatı, partiye girişlerinden sonraki ilk Cumhuriyet Senatosu üyeliği seçimi tarihinde sona erer." TÜRKIYE CUMHURIYYTII ANAYASA MAHKEMESİ (AYM), (1961 Anayasası) https://www.anayasa.gov.tr/tr/mevzuat/onceki-anayasalar/1961-anayasasi// (erişim tarihi: 25.01.2021).

261982 Anayasasında günümüz kadar 19 seferde toplamda 184 değişiklik yapılmıştır. TÜRKIYYE BÜYÜK MILLET MECLISİ (TBMM), Türkiye Cumhuriyeti Anayasas, 
halinde, TBMM üye sayısı 400 olarak öngörülmüş ${ }^{27}$ ve bu madde yalnızca 1983 Milletvekili Genel Seçimlerinde uygulama alanı bulabilmiştir. 17/5/1987 tarih ve 3361 sayılı Kanun'la yapılan Anayasa değişikliğìi ${ }^{28}$ ile TBMM üye sayısı 50 artırılarak 450 sabit sayısına yükseltilmiş ve bu madde de 1987 Milletvekilleri Genel Seçimleri ve 1991 Milletvekilleri Genel Seçimleri olmak üzere yalnızca iki Milletvekili Genel Seçiminde uygulama alanı bulabilmiştir. 23/7/1995 tarih ve 4121 sayılı Kanun'la yapılan Anayasa değişikliği ${ }^{29}$ ile TBMM üye sayısı 100 artarak 550 sabit sayısına yükseltilmiştir ve 1995 ile 2015 tarihleri arasında yapılan toplam 7 Milletvekili Genel Seçimlerinde uygulama alanı bulmuştur. Son olarak 21/01/2017 tarih ve 6771 sayılı Kanun'la yapılan Anayasa değişikliği ${ }^{30}$ ile TBMM üye sayısı 50 arttırılarak 600 sabit sayısına yükseltilmiştir.

\section{1982 Anayasasına göre Milletvekilliği Sayısında Meydana Gelen Değiş̧likler ve Gerekçeleri}

1982 Anayasasının yürürlüğe girmesinin üzerinden yaklaşık beş yıl gibi çok kısa bir süre geçtikten sonra, Anayasanın milletvekili sayısı hakkında hüküm içeren 75 . maddesi değiştirilmiş ve ilk halinde 400 sabit sayı olarak tespit edilen TBMM üye sayısı 50 artırılarak 450 sabit üye sayısı olarak öngörülmüştür. Milletvekili sayısının artırılması istemi ile ilgili anayasa değişikliği teklifi kanunun madde gerekçesinde "TBMM çalışmalarının daha verimli olması ve komisyonlarda gereken sayıda milletvekili katılabilmesinin temin" edilmesi ifadeleri yer almıştır ${ }^{31}$. Bir diğer ifade ile milletvekili sayısının artışı ile yasama organının faaliyetlerinde daha verimli olması ve meclis

https://www.tbmm.gov.tr/anayasa.htm. (erişim tarihi: 14.02.2021). En fazla değişikliğe uğrayan maddelerden biri de 3 değişiklik ile anayasanın yasama organı üye sayısını düzenleyen 75 . maddesidir.

272709 nolu 7 Kasım 1982 Tarihinde Halkoyu ile Kabul Edilen Türkiye Cumhuriyeti Anayasası, RG, 7.11.1982, S. 17863 Mükerrer.

283361 nolu 7.11.1982 Tarih ve 2709 Sayılı Türkiye Cumhuriyeti Anayasasının 67, 75, 175 inci Maddelerinin Değiştirilmesine ve Geçici 4 üncü Maddesinin Yürürlükten Kaldırılması Hakkında Kanun, RG, 17.05.1987, 19464 Mükerrer.

294121 nolu 7.11.1982 Tarih ve 2709 Sayılı Türkiye Cumhuriyeti Anayasasının Başlangıç Metni ve Bazı Maddelerinin Değiştirilmesine Dair Kanun, RG, 23.07.1995, 22355.

306771 sayılı Türkiye Cumhuriyeti Anayasasında Değişiklik Yapılmasına Dair Kanun, RG, 21.01.2017, 29976.

31 17.05.1987 Tarih ve 3361 nolu Kanunla Kabul Edilen Anayasa Değişikliği Madde Gerekçeleri, (S. Say1s1: 564), TBMM Tutanak Dergisi, 13.05.1987, Dönem: 17, Birleşim: 102, Cilt: 40. 
komisyonlarında daha fazla milletvekilinin katılımının sağlanması amaçlandığı ileri sürülmüştür. $\mathrm{Bu}$ madde gerekçesinde belirtilen sebebin dışında Anayasa Komisyonu Raporunda $^{32}$ bu duruma ilişkin başka bir gerekçe ileri sürülmemiştir.

TBMM Genel Kurulu'nda yapılan birinci tur görüşmesinde ${ }^{33}$, Sosyaldemokrat Halkçı Parti (SHP) haricinde, parti grubu adına söz alan milletvekilleri TBMM üye tamsayısının artırılmasına olumlu yaklaştıkları yönünde konuşmalar yapmıştır. Bir diğer ifade ile Doğru Yol Partisi (DYP) ve Demokratik Sol Parti (DSP) grubu adına söz alan milletvekilleri bu anayasa değişikliği teklifini desteklediklerini belirtmiş diğer taraftan SHP grubu adına söz alan milletvekili ise TBMM üye sayısının artırılmasını desteklemedikleri yönünde konuşmalar yapmıştır. Bununla beraber, milletvekilliği sayısının ne kadar artırılması gerektiği noktasında uzlaşı yakalanmış olsa da, bu vekillerin seçim çevrelerine ne şekilde dağıtılması gerektiği noktasında tam bir uzlaşı söz konusu değildir. DYP Grubu adına söz alan Namık Kemal Şentürk, TBMM üye sayısının 400'den 450'ye artırılmasinı desteklediklerini fakat ilave edilecek bu 50 milletvekilliğinin, mevzuatta ilgili değişiklik yapılarak nüfus bakımından büyük illere değil, daha küçük olan illere dağıtılması gerektiğini ileri sürmüştür ${ }^{34}$. DYP'nin bu isteğine mecliste grubu bulunan diğer partilerden DSP haricinde destek gelmemiştir. Genel Kurul'da yapılan görüşme ve oylamalar sonucunda milletvekili sayısının 400'den 450’ye çıkarılmasını öngören anayasa değişikliği teklifi kabul edilmiştir.

1982 Anayasasının yasama organı üye sayısı hakkında hüküm içeren 75. maddesi 23/7/1995 tarih ve 4121 sayılı Kanun'la yapılan Anayasa değişikliği ile ikinci kez değiştirilmiş ve TBMM üye sayısı 100 artırılarak 450'den 550 sabit sayısına yükselmiştir. Anayasa değişikliği kanun teklifi ve bu değişiklik teklifine ilişkin TBMM Genel Kurulu'na sunulan Anayasa Komisyonu Raporunun ilk haline bakıldığında, milletvekili sayısının 100 değil 150 artırılarak 450’den 600'e çıkarılmasının teklif edildiği

\footnotetext{
32 Anayasa Komisyonu Raporu, 08.05.1987, Esas No: 2/438, Karar No: 9, TBMM Tutanak Dergisi, 13.05.1987, Dönem: 17, Birleşim: 102, Cilt: 40.

33 TBMM Tutanak Dergisi, 13.05,1987, Dönem: 17, Birleşim 103, Cilt: 40.

34 Kırsal kesimden daha fazla destek alan Adalet Partisi’nin çizgisinde kurulmuş olan DYP, artırılacak milletvekilliklerinin nüfus bakımından daha küçük illere dağıtılmasını isteyerek aslında milletvekili genel seçimlerinde daha fazla sandalye elde etme amacı taşıdığı da ileri sürülebilir.
} 
görülmektedir ${ }^{35}$. Milletvekili sayısının 450'den 600'e artırılmasına ilişkin anayasa değişikliği teklifi kanununun madde gerekçesinde, artan nüfusun ihtiyaçlarına daha iyi cevap verebilmek adına temsilci sayısının da artırılmasının gerekli görüldüğü ileri sürülmüştür ${ }^{36}$. Bunun yanı sıra Anayasa Komisyonu Raporunda ise temsilci sayısının artırılmasına yönelik üç gerekçe daha ilave edilmiştir ${ }^{37}$. İlk olarak, diğer demokratik ülkeler ile mukayese edildiğinde, Türkiye'deki milletvekili sayısının nüfusa oranla düşük olduğu iddia edilmiştir. İkinci olarak ise, TBMM üye sayısı artışı ile hem yönetilenlerin yönetenlere isteklerini daha iyi bir şekilde sunma imkânının artacağı hem de yönetenler tarafından alınan kararların yönetilenlere izah edilmesinin daha mümkün olacağı ileri sürülmüştür. Son olarak ise, mevcut milletvekili sayısının her parti için parti içi adaylık mücadelesinde sertleşmeye sebebiyet verdiğini, dolayısıyla TBMM üye sayısında artışın sağlanması ile parti içi adaylık mücadelesinin daha yumuşak olmasının amaçlandığı ileri sürülmüştür.

Anayasa değişikliği teklifi kanununun milletvekili sayısının 450'den 600'e çıkarılmasına ilişkin maddesinin TBMM Genel Kurulu'nda yapılan birinci tur görüşmesinde ${ }^{38}$, parti grubu andına söz alan milletvekillerinin hemen hemen hepsi farklı gerekçelerle de olsa bu anayasa değişikliği teklifine taraf olmadıkları yönünde konuşma yapmışlardır. Bu dönem mecliste bulunan partilerden, bu değişiklik teklifine ilişkin parti grubu adına söz alan Refah Partisi (RP), Cumhuriyet Halk Partisi (CHP) ve Anavatan Partisi (ANAP) milletvekilleri bu anayasa değişikliği teklifini desteklemediklerini ifade etmişlerdir. $\mathrm{Bu}$ madde ile ilgili olarak TBMM Genel Kurulu'nda yapılan birinci tur görüşmelerde parti grubu adına söz alan milletvekillerinin olumlu görüş beyan etmemelerinin üzerine Anayasa Komisyonu bu değişiklik teklifini değiştirmek üzere komisyona geri almış ve milletvekili sayısının 600'e değil 550’ye çıkarılması teklifini

35 23.07.1995 Tarih ve 4121 nolu Kanunla Kabul edilen Anayasa Değişikliği Madde Gerekçeleri ve Anayasa Komisyonu Raporu (S. Sayıs1: 861), TBMM Tutanak Dergisi, 14.06.1995, Dönem: 19, Birleşim: 123, Cilt: 88 .

36 Anayasa Komisyonu Raporu (S. Sayısı: 861)

37 Anayasa Komisyonu Raporu (S. Sayısı: 861)

38 TBMM Tutanak Dergisi, 23.06.1995, Dönem: 19, Birleşim; 128, Cilt: 89. 
TBMM Genel Kurulu'na geri sunmuştur ${ }^{39}$. Milletvekili sayısının 450'den 550 sabit sayısına çıkarılması ile ilgili TBMM Genel Kurulu'nda yapılan birinci tur oylamada ${ }^{40}$ beşte üç çoğunluğa ulaşılamamıştır. İkinci tur oylamada ve kanun metninin tamamının oylanmasında ise 1982 Anayasasının aradığı çoğunluğa ulaşılmıştır. İkinci tur oylamada beşte üç çoğunluğa ulaşılmış ve kanun metninin hepsinin oylanmasında ise üçte ikinin üzerinde çoğunluğa ulaşılarak anaysa değişikliği teklifi kabul edilmiştir ${ }^{41}$.

Son olarak, 16 Nisan 2017 tarihinde gerçekleşen referandumda kabul edilen Anayasa değişikliği ile 1982 Anayasasının 75. maddesi üçüncü kez değiştirildi ve TBMM üye sayısı 50 artırılarak, 550'den 600 tam sayısına yükseltildi. Anayasa değişikliği teklifi kanununun madde gerekçesinde "ülkemizin nüfus artışına uygun olarak milletvekili sayısı altıyüze çıkarılmaktadır” denilerek ${ }^{42}$, nüfus artışı, temsilci sayısının artırılması istemine gerekçe olarak sunulmuştur. TBMM Genel Kurulu'na sunulan Anayasa Komisyonu Raporunda ${ }^{43}$ TBMM üye sayısının 550'den 600'e yükseltilmesine dair ayrıca bir gerekçe belirtilmemiştir.

$\mathrm{Bu}$ anayasa değişikliği teklifi ile ilgili olarak TBMM Genel Kurulu'nda yapılan birinci tur görüşmelerde ${ }^{44}$ parti grubu adına söz alan CHP ve Halkların Demokratik Partisi (HDP) milletvekilleri bu anayasa değişiklik teklifine karşı olduklarını yönünde Milliyetçi Hareket Partisi (MHP) ve Adalet ve Kalkınma Partisi (AKP) ise taraf oldukları yönünde konuşmalar yapmıştır. MHP haricinde parti grubu adına söz alan

39 Anayasa değişikliği teklifi kanunun bu maddesinin ilk hali: "Türkiye Büyük Millet Meclisi genel oyla seçilen altıü̈z milletvekilinden oluşur. Bu milletvekillerinin yüz adedi ülke çapındaki seçim çevresinden seçilir" şeklinde olup, "Bu milletvekillerinin yüz adedi ülke çapındaki seçim çevresinden seçilir" fikrası da madde metninden çıkarılmıştır. TBMM Tutanak Dergisi, 23.06.1995, Dönem: 19, Birleşim; 128: Cilt: 89.

40 Yapılan gizli oylama sonucunda, oylamaya 363 Milletvekili iştirak etmiş ve 265 'i kabul, 96'sı ret ve 2'si çekimser yönde oy kullanmıştır. TBMM Tutanak Dergisi, 28.06.1995, Dönem: 19, Birleşim: 131, Cilt: 90 .

411982 Anayasası için Anayasa değişikliği teklifi oylamalarda gerekli karar yeter sayıları için bakınız, AKÇA, Kürşat, "Türk Mevzuat ve Uygulaması Çerçevesinde Anayasa Değişikliği İçin TBMM'de Yapılan Oylamalar ve Bu Oylamalarda Aranan Karar Yeter Sayısı" Dicle Üniversitesi Hukuk Fakültesi Dergisi, Y11: 2017, Cilt: 22, Say1: 36, (s. 31-58).

42 21.01.2017 Tarih ve 6771 nolu Kanunla Kabul Edilen Anayasa Değişikliği Madde Gerekçeleri, (S. Sayıs1: 447), TBMM Tutanak Dergisi, 09.01.2017, Dönem: 26, Birleşim: 53, Cilt: 31.

43 TBMM Tutanak Dergisi, (S. Sayısı: 447)

44 TBMM Tutanak Dergisi, 10.01.2017, Dönem: 26, Birleşim: 54, Cilt: 31. 
milletvekillerinin konuşmaları içerik olarak milletvekilliği sayısının artırılmasından ziyade, anayasa değişikliği teklifi içerisinde yer alan ve daha sonra görüşülecek olan hükümet sistemi üzerine yoğunlaşmaktadır. TBMM Genel Kurulu'nda yapılan birinci tur ve ikinci tur gizli oylamada milletvekili sayısının 550'den 600 sabit sayısına çıkarılması anayasanın aradığı çoğunluk ile kabul edilmiştir. Hem birinci turda hem de ikinci turda yapılan gizli oylamada beşte üçten fazla fakat üçte ikiden az bir çoğunluğa ulaşılmıştır.

Yukarıda açıklandığımız üzere, 1982 Anayasasının TBMM üye sayısının düzenleyen 75. maddesi üç defa değiştirilmiştir. Milletvekili sayısının artırılmasına yönelik anayasa değişikliği teklifi kanunlarının madde gerekçeleri ve TBMM Genel Kurul görüşmeleri dikkate alındığında, ilk değişiklik teklifinin ikinci ve üçüncü değişiklik tekliflerinden farklı olduğu göze çarpmaktadır. Bununla beraber ikinci ve üçüncü değişiklik tekliflerinin madde gerekçelerinin aynı olduğu görülmektedir. İlk değişiklik teklifinin madde gerekçesinde yasama organının faaliyetlerinin daha verimli olması ve komisyonlarda daha fazla temsilcinin katılımının sağlanması amaçlandığı ifade edilmektedir. Buna karşın, ikinci ve üçüncü değişiklik tekliflerinin madde gerekçesinde ise nüfus artışının temsilci sayısının artırılmasına gerekçe olarak sunulduğu görülmektedir. Bununla beraber, ikinci değişiklik teklifinin TBMM Genel Kurulu'na sunulan Anayasa Komisyonu Raporunda artan nüfusun yanında üç gerekçe daha eklendiği, üçüncü değişiklik teklifinin TBMM Genel Kurulu'na sunulan Anayasa Komisyonu Raporunda ise TBMM üye sayısının artırılması istemine artan nüfus harici başka bir gerekçe ileri sürülmemesi göze çarpmaktadır.

TBMM Genel Kurulu'nda yapılan görüşmelere bakacak olursak milletvekili sayısının 400'den 450'ye artırılmasını öngören anayasa değişiklik teklifinin neredeyse TBMM'de bulunan bütün partiler tarafından desteklenirken, milletvekili sayısının 450'den 600'e yükseltilmesini öngören ikinci anayasa değişiklik teklifinin ise nerdeyse TBMM'de bulunan bütün siyasi partiler tarafından karşı çıkıldığı gözlemlenebilir. Yukarıda da ifade edildiği gibi, TBMM üye sayısını 450'den 600'e çıkarmayı amaçlayan anayasa değişikliği teklifinin mecliste tartışmalara sebebiyet verdiği görülmektedir. Sonuç olarak, bu madde Anayasa Komisyonu tarafından redaksiyon için geri çekilip milletvekili sayısını 450'den 600'e değil de 450'den 550'e yükseltilmesini şeklinde 
değiştirilmiştir. Her ne kadar ikinci tur oylamada ve kanunun metninin tamamının oylamasında anayasanın aradığı çoğunluğa ulaşılmış olsa da özellikle ilk tur oylamada beşte üç çoğunluğa ulaşamamış olması bu değişiklik teklifinin ilk etapta mecliste bulunan milletvekilleri tarafindan ne derece benimsendiği konusunda bir fikir vermektedir.

TBMM Genel Kurulu'nda parti grubu adına söz alan milletvekillerinin yaptıkları konuşmalar içerik olarak dikkate alındığında, ilk iki anayasa değişikliği teklifinde, genellikle milletvekili sayısındaki değişiklik üzerine odaklanıldığı, diğer taraftan üçüncü

değişiklik teklifinde ise MHP hariç parti grubu adına söz alan milletvekillerinin daha sonra görüşülecek olan hükümet sistemiyle ilgili anayasa değişiklikleri teklifi üzerine durdukları ifade edilebilir.

1987 ve 1995 yıllarında gerçekleşen Anayasa değişiklikleri ile hem TBMM üye sayısında hem de seçmen yaşında değişikliğe gidilmiştir. Kabul edilen bu Anayasa değişiklikleri ile TBMM üye sayısı artarken, seçmen yaşı düşürülmüştür. 1987 yılındaki Anayasa değişikliği ile seçmen yaşı 21'den 20'ye ve 1995 yılındaki Anayasa değişikliği ile seçmen yaş1 20'den 18'e düşürülmüştür. Benzer durum 2017 y1lında gerçekleşen Anayasa değişikliği için söz konusu değildir. Bir diğer ifade ile 2017 yılındaki Anayasa değişikliği ile TBMM üye sayısı artırılmış fakat seçmen yaşında bir değişikliğe gidilmemiştir. 1987 ve 1995 yıllarında gerçekleşen Anayasa değişikliklerinde hem TBMM üye sayısının artmış hem de seçmen yaşının düşürülmüş olması bu iki durum arasında bir ilişki kurulabileceği düşüncesini akla getirebilir. Fakat Türkiye'de seçim çevrelerinin çıkaracakları milletvekili sayısının hesaplanmasında, seçmen sayısının değil nüfusun esas alınması bu iki durum arasında ilişki kurulma olasılığını azaltacak mahiyettedir.

\section{TÜRKIYYE ve OECD ÜLKELERİ MILLET MECLISİ ÜYE SAYILARI: KÜPKÖK YASASI}

\section{A. OECD Ülkeleri Millet Meclisi Üye Sayıları: 1969-2019}

Ülkemizde yaklaşık olarak son 50 yıl dikkate alındığında, yukarıda da bahsedildiği üzere, genel eğilim yasama organı üye sayısını artırmaya yönelik olmuştur. Türkiye 
haricinde diğer ülkelerin millet meclisi üye sayılarının zaman içerisinde değişiklik gösterip göstermediğine baktığımızda, kimi ülkelerin millet meclisi üye sayılarının değişmediği, kimi ülkelerin millet meclisi üye sayılarının azaldığı ve kimi ülkelerin millet meclisi üye sayılarının ise arttığı gözlenmektedir. Bu durum ile ilgili olarak Tablo 1'de günümüz OECD üyesi 30 ülkenin 50 yıl önceki millet meclisi üye sayıları ile günümüz millet meclisi üye sayıları verilmiştir. Tablo 1'de görüleceği üzere, aralarında Amerika Birleşik Devletleri $^{45}$, İtalya ${ }^{46}$ ve Yunanistan'1nda bulunduğu 10 ülkenin millet meclisi üye sayısı 50 yıl önceki millet meclisi üye sayısı ile aynıdır. Bununla beraber aralarında, Birleşik Krallık ${ }^{47}$, İsveç ve Kanada'nın da bulunduğu 15 ülkenin günümüz millet meclisi üye sayısı 50 önceki millet meclisi üye sayısından daha yüksektir. Son olarak, aralarında İspanya ve Belçika'nın da bulunduğu beş ülkenin millet meclisi üye sayısı 50 yıl önceki millet meclisi üye sayısından daha düşüktür ${ }^{48}$. Diğer taraftan, aralarında Fransa, Macaristan, İrlanda, Japonya, Meksika, Hollanda, Portekiz, Romanya ve Birleşik Krallığın da bulunduğu çok sayıda ülkenin millet meclisi üye sayısını azaltmaya yönelik girişimleri mevcuttur ${ }^{49}$.

45 ABD'de yaklaşık yüz yıl önce 435'e sabitlenen Temsilciler Meclisi üye sayısının artırılması gerektiğini ileri süren görüşler için bakınız, FREDERICK, 2010, s. 10; LADEWIG / JASINSKI, 2008, s. 99; LIJPHART, 1998, s. 12.

46 21-22 Eylül 2020 tarihinde gerçekleşen Anayasa değişikliği referandumun kabulü ile İtalya'da Temsilciler Meclisi üye sayısının 400'e düşürülmesi kabul edildi. BBC, Italians vote to slash size of parliament by a third, https://www.chicagomanualofstyle.org/tools citationguide/citation-guide1.html\#cg-website, (erişim tarihi: 12.02.2021).

47 Birleşik Krallık'ta yasama organının alt kanadını oluşturan Avam Kamarası üye sayısı 20. yüzyıl boyunca 600'ün altına hiç düşmemiştir. NORTON, Philip, "The Individual Member in the British House od Commons: Facing both Ways and Marching Forward", The Journal of Legislative Studies, Yıl: 1999, Cilt: 5, Sayı: 3-4, s. 53. Hali hazırda 650 üyeli Avam Kamarasının üye sayısının 600'e indirilmesine yönelik teşebbüsler mevcuttur. JOHNSTON, Ron / ROSSITER, David / PATTIE, Charles, "When is a Gerrymander Not a Gerrymander: Who Benefits and Who Loses from the Changed Rules for Defining Parliamentary Constituencies?", The Political Quarterly, Y11: 2017, Cilt: 88, Sayı: 2, s. 215.

48 Millet meclisi üye sayısının artmasına, nüfus artısııın ve etkin parti sayısının, millet meclisi üye sayısının azalmasına ise yaşanan ekonomik krizlerin tesir ettiği ifade edilmektedir, bkz. JACOBS / OTJES, 2015.

49 MARGARITONDO, Giorgio, "Size of National Assemblies: The Classic Derivation of the Cube-Root Law is Conceptually Flawed" Frontiers in Physics, Y11: 2021, s.1 
Tablo 1: OECD Ülkeleri Millet Meclisi Üye Sayıları: 1969-2019

\begin{tabular}{|c|c|c|c|}
\hline Ülke Adı & $\begin{array}{l}\text { Millet } \quad \text { Meclisi } \\
\text { Üye Sayısı } 1969\end{array}$ & \begin{tabular}{|lr} 
Millet & Meclisi \\
Üye & Sayısı \\
2019 &
\end{tabular} & $\begin{array}{l}\text { Değişiklik } \\
\text { Durumu }\end{array}$ \\
\hline Avustralya & 124 & 150 & 26 Artt 1 \\
\hline Avusturya & 165 & 183 & 18 Arttı \\
\hline Belçika & 212 & 150 & 62 Azaldi \\
\hline Kanada & 264 & 338 & 74 Artt1 \\
\hline Şili & 147 & 155 & 8 Artt1 \\
\hline Kolombiya & 190 & 172 & 18 Azald $_{1}$ \\
\hline Kosta Rika ${ }^{50}$ & 57 & 57 & Değiş̧medi \\
\hline Danimarka & 179 & 179 & Değiş̧medi \\
\hline Finlandiya & 200 & 200 & Değişmedi \\
\hline Fransa & 480 & 577 & 97 Artt1 \\
\hline Yunanistan & 300 & 300 & Değişmedi \\
\hline Macaristan & 349 & 199 & 150 Azald 1 \\
\hline İzlanda & 60 & 63 & 3 Artt1 \\
\hline İrlanda & 144 & 158 & 14 Arttı \\
\hline İsrail & 120 & 120 & Değiş̧medi \\
\hline İtalya & 630 & 630 & Değişmedi \\
\hline
\end{tabular}

50 Kosta Rika henüz OECD üye olmamakla beraber, üye sürecinde olan bir ülke olduğu için listeye alınmıştır, OECD, OECD accession candidades, https://www.oecd.org/about/members-and-partners/ (erişim tarihi: 15.02.2021). 


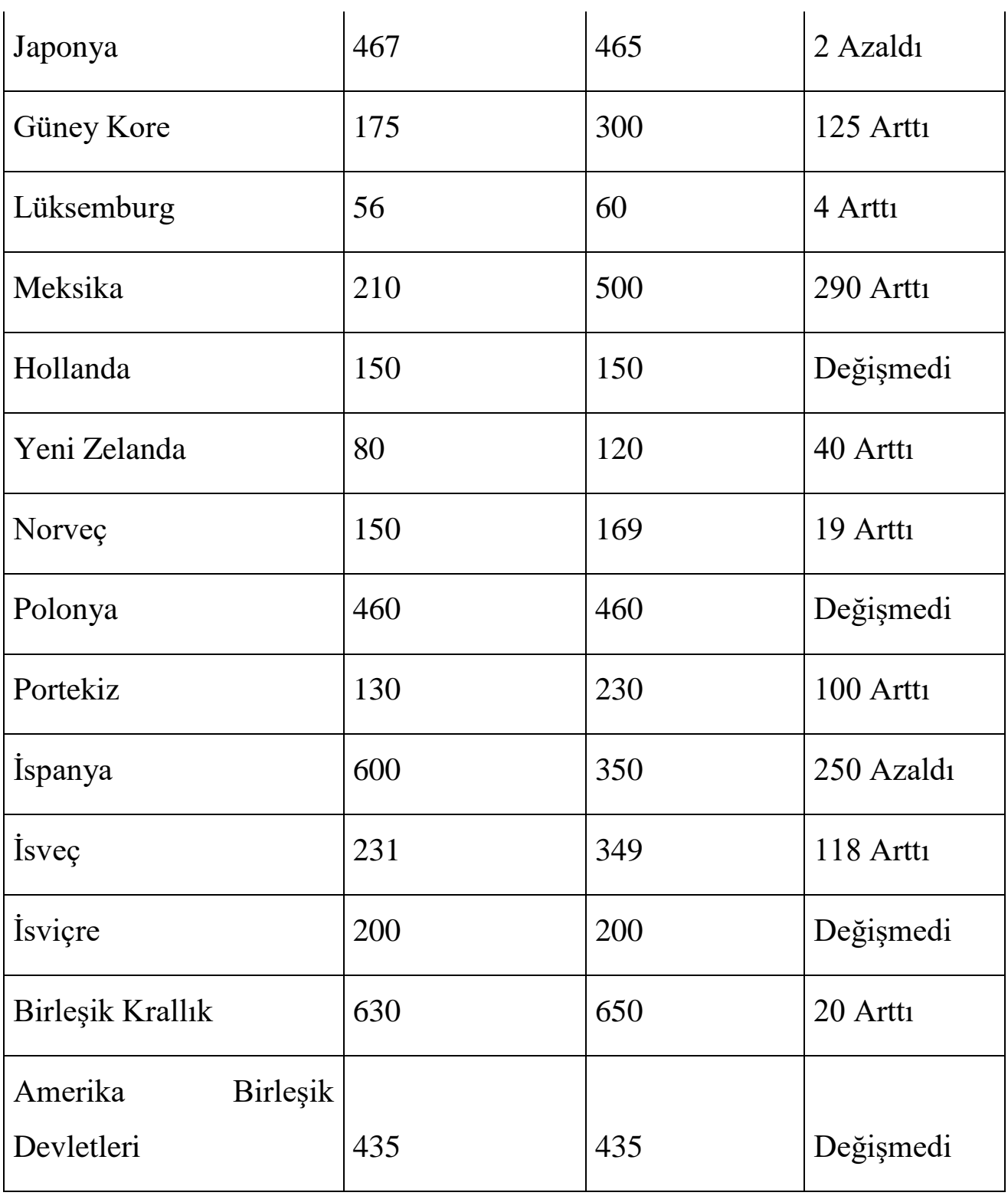

Kaynak: 1969 yılına ait millet meclisi üye sayıları hakkındaki veriler, Rein Taagepera'nın Millet Meclisi Büyüklüğü (The Size of National Assemblies) isimli çalışmasından alınmıştır ${ }^{51} .2019$ yılına ait millet meclisi üye sayıları hakkındaki veriler OECD'nin web sitesinden alınmıştır ${ }^{52}$.

51 TAAGEPERA, Rein, , "The Size of National Assemblies”, Social Science Research, Y11; 1972, Cilt: 1, Say1: 4, (s. 395-397).

52 OECD, Government at a Glance Contextual Factors, http://www.oecd.org/gov/government-at-aglance-2019-contextual-factors.pdf, (erişim tarihi: 24.01.2021). 
Son 50 yılda, millet meclisi üye sayısında artışın meydana geldiği ülkeler içerisinde Meksika 290 üye sayısı artışı ile en fazla millet meclisi üye sayısı artışının yaşandığı ülke olurken, bu ülkeyi 150 ile Türkiye ${ }^{53}, 125$ ile Güney Kore, 100 ile Portekiz ve 97 millet meclisi üye sayısı artışı ile Fransa takip etmektedir. Millet meclisi üye sayısında artışın meydana geldiği ülkeler içerisinde 8 ülkenin millet meclisi üye sayısı 3 ile 26 arasında değişen miktarlarda artmıştır. Millet meclisi üye sayısında azalışın meydana geldiği ülkeler içerisinde İspanya 250 üye sayısı azalışı ile en fazla millet meclisi üye sayısı azalışının yaşandığı ülke olurken, bu ülkeyi 150 ile Macaristan ve 62 ile Belçika takip etmektedir.

\section{B. OECD Ülkeleri ve Küpkök Yasası}

Tablo 1'de yer alan ülkelerin üçte ikisinin 50 yıl önceki millet meclisi üye sayısı ile günümüz millet meclisi üye sayısı birbirinden farklıdır. Bununla beraber, Tablo 1'de yer alan ülkelerin millet meclisi üye sayıları birbirleri ile mukayese edildiğinde, hem 50 yıl önce hem de günümüzde birbirinden farklı oldukları dikkat çekmektedir. Bu durum “ülkelerin millet meclisi büyüklükleri neden birbirinden farklıdır?” ya da "millet meclisi üye sayısını belirleyen faktörler var mıdır, var ise bunlar nelerdir?" gibi soruları akıllara getirmektedir. Millet meclisi üye sayısını etkileyen faktörlerin neler olduğu üzerine yapılmış çalışma sayısı oldukça sınırlı olmakla beraber bunlar içerisinde Rein Taagepera tarafından kaleme alınan Millet Meclisi Büyüklüğ̈̈ ${ }^{54}$ isimli makale literatürde ayrı bir öneme sahiptir ${ }^{55}$. Taagepera millet meclisi üye sayısını etkileme ihtimali olan başlıca sekiz $^{56}$ faktör bulunduğunu ve bunlar içerisinde ülke nüfusunun neredeyse en önemlisi

531969 yılında Türkiye'de Millet Meclisi üye sayısı 450 idi. Dolayısıyla 1969 ile 2019 arasında Millet Meclisi üye sayısı farkı 150'dir.

54 TAAGEPERA, 1972,

55 JACOBS / OTJES, 2015, s. 281.

56 Millet meclisi üye sayısını etkileme ihtimali olan faktörler şunlardır: "a) ülke nüfusu, b) ekonomik gelişmişlik düzeyi, c) sosyal hareketlilik derecesi, d) ülkenin bağımsızlık düzeyi, e) seçilme yöntemleri: seçim ya da atama yoluyla oluşan meclis, f) meclisi işlevi: karar verme, danı̧̧ma ya da onay, g) ilk kurulan meclisin örnek alınması, h) kişisel ve ülkenin kendine has durumlar” TAAGEPERA, 1972, s. 386. 
olduğunu ileri sürer ${ }^{57}$. Taagepera'ya göre millet meclisi üye sayısı ile ülke nüfusu arasında bir ilişki mevcuttur ${ }^{58}$ ve millet meclisi üye sayısı ülkenin nüfusunun küpköküne eşit olma eğilimindedir. Taagepera'nın küpkök yasasının demokratik ülkelerin millet meclisi üye sayısı ile ülke nüfusu oranını neredeyse tam olarak açıkladığı ileri sürülmektedir ${ }^{59}$.

\section{Figür 1: Küpkök Yasası: OECD ülkeleri Nüfusu ve Millet Meclisi Üye Sayıları ${ }^{60}$}

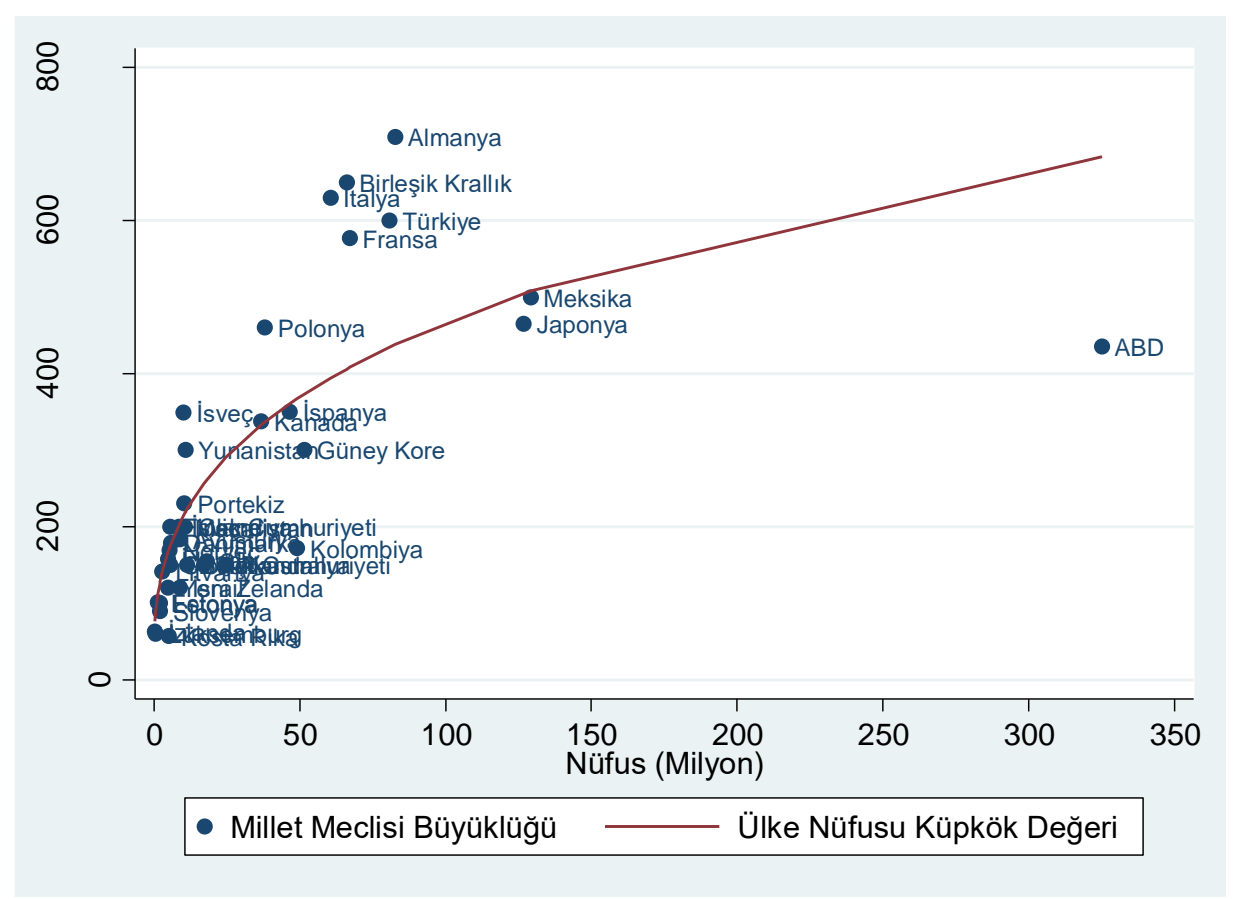

\section{Kaynak: OECD Government at a Glance, Contextual Factors ${ }^{61}$}

Figür 1'de günümüz Türkiye dâhil OECD üyesi 37 ülke ve OECD'ye adaylık sürecinde olan Kosta Rika'nın nüfus ile millet meclisi üye sayıları verilmiştir. Figür

57 Demokratik ülkelerde millet meclisi büyüklüğünü etkileyen faktörlerin neler olduğunu inceleyen Jacobs ve Otjes siyasi parti gibi nüfus harici faktörlerin olduğunu ve bunların henüz yeterince çalışılmadığını ileri sürer, JACOBS / OTJES, 1972, s. 282.

58 TAAGEPERA, 1972, s. 385.

59 LADEWIG / JASINSKI, 2008, s. 99.

60 Figür 1, Ladewig ve Jasinski tarafından yapılan 2004 yılına ait veriler 1şı̆̆ında yapılan "Nüfus büyüklüğü alt meclis: OECD ülkeleri” (Polulation sizes and lower chamber, OECD countries), isimli Figür'den esinlenilerek yapılmıştır. LADEWIG / JASINSKI, 2008, s. 99.

61 Ülke nüfusuna ilişkin veriler 2017 yılına, millet meclisi üye sayısına ilişkin verileri ise 2019 yılına aittir. Ayrıntılı bilgi için ayrıca bakınız, OECD, (Government at a Glance Contextual Factors) 
1'deki eğri ülke nüfusunun küpkökünü vermektedir. Bu eğrinin sağ iç kısmında yer alan ülkelerin millet meclisi üye sayıları, ülke nüfusunun küpkökünün altındadır, eğrinin üzerinde (sol tarafinda) yer alan ülkelerin millet meclisi üye sayıları ise nüfuslarının küpkökünden daha fazladır.

Figür 1'de görüldüğü üzere, günümüz OECD üyesi 37 ülkeden Türkiye'nin de içerisinde bulunduğu sadece 8 tanesinin millet meclisi üye sayısı, nüfusunun küpkökünden daha fazladır. Bu ülkeler, Almanya, Birleşik Krallık, İtalya, Türkiye, Fransa, Polonya, İsveç ve Yunanistan'dır. Bu ülkeler içerisinden İtalya'da 20-21 Eylül 2020 tarihinde gerçekleşen Anayasa değişikliği referandumunda millet meclisi sayısının 630'dan 400'e düşürülmesi önerisi kabul edildi. Dolayısıyla, İtalya'nın önümüzdeki dönem millet meclisi üye sayısı, nüfusunun küpköküne çok yakın bir değerde olacaktır. Bununla beraber, Fransa ${ }^{62}$ ve Birleşik Krallık'ta ${ }^{63}$ millet meclisi üye sayısını azaltmaya yönelik girişimler mevcuttur.

Diğer taraftan, Türkiye'de son 40 yıl içerisinde milletvekili sayısı ülke nüfusunun küpkökünün üzerinde olmasına karşın üç defa değişikliğe uğramış ve hepsinde de bu sayı arttırılmıştır. Son olarak, temsilci sayısı son 50 yılda en fazla artış gösteren ülke olan Meksika'nın millet meclisi üye sayısının nüfusunun küpkökü düzeyinde olduğunu belirtmekte fayda vardır.

\section{MILLETVEKİI SAYISININ DEĞİŞMESININ SEÇIM ÇEVRELERİNE ETKİSİ}

16 Nisan 2017 Anayasa değişikliği referandumunun kabul edilmesiyle birlikte, hükmet sistemi değişikliğinin yanı sıra, TBMM üye sayısı 550'den 600'e çıkmış oldu. Milletvekili sayısında meydana gelen artış, seçim çevresi sayını ve seçim çevrelerinden seçilecek milletvekili sayısını da etkilemiş oldu. Seçim çevrelerinin sayısı ve seçim

\footnotetext{
62 MARGARITONDO, 2021, s. 1; FRANCE24, Franch Government wants to scrap number of MPs by 25 percent, https://www.france24.com/en/20190829-french-government-wants-scrap-number-mps25-percent, (erişim tarihi: 12.02.2021).

63 MARGARITONDO, 2021, s. 1; JOHNSTON / ROSSITER / PATTIE, 2017, s.215.
} 
çevrelerinin çıkaracağı milletvekili sayısı ile ilgili hüküm 2839 sayılı Milletvekili Seçimi Kanunu'nun 4. maddesinde düzenlenmektedir.

Milletvekili sayısının 550'den 600'e çıkarılması ilk kez 24 Haziran 2018 Milletvekili Genel Seçimlerinde uygulama alanı buldu. Aşağıda yer alan Tablo 2'de, artan milletvekili sayısının seçim çevresi sayısına ve seçim çevresinden seçilen milletvekili sayısına etkisinin ne olduğunu konu edinmektedir. Tablo 2'de, 24 Haziran 2018 Milletvekili Genel Seçimlerinde eğer 550 milletvekili seçilseydi, seçim çevreleri sayısının ve bu seçim çevrelerinin çıkaracağı milletvekili sayılarının ne olacağına dair bilgiler yer almaktadır. Bu tabloda aynı zamanda, YSK'nın 2018/263 sayılı kararına göre 24 Haziran 2018 Milletvekili Genel Seçimlerinde seçim çevreleri sayısı ve bu seçim çevrelerin çıkaracağı milletvekili sayısını da göstermektedir.

Tablo 2: 24 Haziran 2018 Milletvekili Genel Seçimler Seçim Çevreleri ve Seçim Çevresi Başına Düşen Milletvekili Sayısı

\begin{tabular}{|c|c|c|c|c|c|}
\hline Seçim Çevresi & $\begin{array}{l}\text { Milletvekil } \\
\text { i Sayısı } 600\end{array}$ & $\begin{array}{l}\text { Milletvekil } \\
\text { i Sayısı } 550 \\
\text { Olsaydı }\end{array}$ & Seçim Çevresi & $\begin{array}{l}\text { Milletvekil } \\
\text { i Sayısı } 600\end{array}$ & $\begin{array}{l}\text { Milletvekil } \\
\text { i Sayısı } 550 \\
\text { Olsaydı }\end{array}$ \\
\hline Adana & 15 & 14 & Kirklareli & 3 & 3 \\
\hline Adiyaman & 5 & 5 & Kırşehir & 2 & 2 \\
\hline $\begin{array}{l}\text { Afyonkarahisa } \\
\mathrm{r}\end{array}$ & 6 & 5 & Kocaeli & 13 & 12 \\
\hline Ağr1 & 4 & 4 & Konya & 15 & 14 \\
\hline Amasya & 3 & 3 & Kütahya & 5 & 4 \\
\hline Ankara I & 13 & 18 & Malatya & 6 & 6 \\
\hline Ankara II & 11 & 15 & Manisa & 10 & 9 \\
\hline Ankara III & 12 & & $\begin{array}{l}\text { Kahramanmara } \\
\text { ş }\end{array}$ & 8 & 8 \\
\hline
\end{tabular}




\begin{tabular}{|c|c|c|c|c|c|}
\hline Antalya & 16 & 15 & Mardin & 6 & 6 \\
\hline Artvin & 2 & 2 & Muğla & 7 & 6 \\
\hline Aydın & 8 & 7 & Muş & 4 & 3 \\
\hline Balıkesir & 9 & 8 & Nevşehir & 3 & 3 \\
\hline Bilecik & 2 & 2 & Niğde & 3 & 3 \\
\hline Bingöl & 3 & 3 & Ordu & 6 & 5 \\
\hline Bitlis & 3 & 3 & Rize & 3 & 3 \\
\hline Bolu & 3 & 3 & Sakarya & 7 & 7 \\
\hline Burdur & 3 & 3 & Samsun & 9 & 9 \\
\hline Bursa I & 10 & 18 & Siirt & 3 & 3 \\
\hline Bursa II & 10 & & Sinop & 2 & 2 \\
\hline Çanakkale & 4 & 4 & Sivas & 5 & 5 \\
\hline Çankırı & 2 & 2 & Tekirdağ & 7 & 7 \\
\hline Çorum & 4 & 4 & Tokat & 5 & 5 \\
\hline Denizli & 8 & 7 & Trabzon & 6 & 6 \\
\hline Diyarbakır & 12 & 11 & Tunceli & 2 & 1 \\
\hline Edirne & 4 & 3 & Şanlıurfa & 14 & 13 \\
\hline Elazı ̆ & 5 & 4 & Uşak & 3 & 3 \\
\hline Erzincan & 2 & 2 & Van & 8 & 7 \\
\hline Erzurum & 6 & 5 & Yozgat & 4 & 3 \\
\hline Eskişehir & 7 & 6 & Zonguldak & 5 & 4 \\
\hline
\end{tabular}




\begin{tabular}{|c|c|c|c|c|c|}
\hline Gaziantep & 14 & 13 & Aksaray & 4 & 3 \\
\hline Giresun & 4 & 4 & Bayburt & 1 & 1 \\
\hline Gümüşhane & 2 & 2 & Karaman & 3 & 2 \\
\hline Hakkari & 3 & 3 & Kırıkkale & 3 & 3 \\
\hline Hatay & 11 & 10 & Batman & 5 & 4 \\
\hline Isparta & 4 & 4 & Şırnak & 4 & 4 \\
\hline Mersin & 13 & 11 & Bartın & 2 & 2 \\
\hline İstanbul I & 35 & 31 & Ardahan & 2 & 2 \\
\hline İstanbul II & 28 & 26 & Iğdır & 2 & 2 \\
\hline İstanbul III & 35 & 31 & Yalova & 3 & 2 \\
\hline İzmir I & 14 & 13 & Karabük & 3 & 2 \\
\hline İzmir II & 14 & 13 & Kilis & 2 & 2 \\
\hline Kars & 3 & 3 & Osmaniye & 4 & 4 \\
\hline Kastamonu & 3 & 3 & Düzce & 3 & 3 \\
\hline Kayseri & 10 & 9 & & & \\
\hline
\end{tabular}

Kaynak: Milletvekili sayısının 600 olduğu durumda seçim çevresi başına düşen milletvekili sayısı YSK'nın 2018/263 sayılı kararından alınmıştır ${ }^{64}$. Milletvekili sayısının 550 olduğu durumda seçim çevrelerinin çıkaracağı milletvekili sayıları 2839 sayı1ı Milletvekili Seçimi Kanunu'nun 4. maddesi uyarınca yazar tarafından hesaplanmıştır ${ }^{65}$.

64 YÜKSEK SEÇIM KURULU, Seçim Çevreleri, https://www.ysk.gov.tr/doc/karar/dosya/77539/2018263.pdf, (erişim tarihi: 06.02.2021).

65 Seçim çevreleri sayısı ve seçim çevrelerinin çıkaracağı milletvekili sayısı hesaplanırken TÜiK'in 2017 Aralık ayına ait nüfus verileri kullanılmıştır, TÜRKIYE İSTATISTIK KURUMU (TÜIK), Adrese Dayalı Nüfus Kayıt Sistemi Sonuçları", https://data.tuik.gov.tr/Bulten/Index?p=Adrese-DayaliNufus-Kayit-Sistemi-Sonuclari-2017-27587. (erişim tarihi: 08.02.2021). Ankara, İstanbul ve İzmir 
Tablo 2'de görüldüğü üzere, milletvekilliği sayısının 550'den 600'e yükselmesi, seçim çevreleri sayısının 85 'ten 87'e çıkmasına sebebiyet vermiştir. Ankara'da seçim çevresi sayısı 2'den 3'e, Bursa'da ise seçim çevresi sayısı 1'den 2'ye çıkmıştır. Bununla beraber, 37 seçim çevresinin milletvekilliği sayısında artış meydana gelmiştir ${ }^{66}$. İl bazında baktığımızda ise, milletvekili sayısı en fazla artan il 10 ile İstanbul olurken, İstanbul'u, 3 ile Ankara, 2 ile Bursa ve İzmir illeri takip etmektedir. Milletvekilli sayısının artması aynı zamanda seçim çevresi başına düşen temsilci sayısının azda olsa yükselmesine sebebiyet vermiştir. Milletvekili sayısı 550 olduğu durumda, seçim çevresi başına düşen ortalama milletvekili sayısı 6,47 iken, milletvekili sayısı 600 olduğunda bu oran 6,90'dir. Diğer taraftan, 45 seçim çevresinin çıkaracağı milletvekili sayısında değişiklik meydana gelmemiştir.

\section{SONUÇ}

Günümüzde demokrasi yönetim anlayışını benimsemiş ülkelerin en önemli kurumlarının başında hiç şüphesiz yasama organı gelmektedir. Yasama organı üyelerinin ne şekilde belirlendiği, bu üyelerin sahip olması gereken özelliklerin neler olduğu ve yasama organının büyüklüğü bugün hala değişikliğe uğramakta ve dolayısıyla bu değişiklilerin gerekçeleri ve etkileri hem teorik hem de ampirik anlamda çalışılmaktadır. Bu çalışma öncelikli olarak, Türkiye'deki yasama organı üye sayısını ele almaktadır. Türkiye'de, 1982 Anayasasının TBMM üye sayısı hakkında hüküm içeren 75. maddesi bu güne kadar üç kez değiştirilmiş ve hepsinde de milletvekilliği sayısı artırılmıştır. Bu çalışma, ilk olarak, 1982 Anayasasının yasama organı üye sayısını belirleyen 75 .

illerinin ilçelerine ait nüfus verilerine ise buradan ulaşı1lmıştır: NUFUSU.COM, Türkiye Nüfusu, https://www.nufusu.com/, (erişim tarihi: 14.01.2021). 24 Haziran 2018 Milletvekili Genel Seçimlerinde Milletvekili sayısı eğer 550 olsaydı, Ankara ilinin çıkaracağı milletvekili sayısı 33 olacaktı, dolayısıyla Milletvekili Seçimi Kanunu'na göre Ankara'nın 2 seçim çevresine ayrılması gerekecekti (m.4). Ankara ilinin 2 seçim çevresine ayrılması durumunda, bu seçim çevrelerinin hangi ilçeleri kapsayacağı, YSK'nın önceki kararları dikkate alınarak belirlendi. YSK, 24. Dönem Milletvekili Genel Seçimi, İllerin Çıkaracağı Milletvekili Sayıları, https://www.ysk.gov.tr/tr/12-haziran-2011-xxiv-donemmilletvekili-genel-secimi/4929, (erişim tarihi: 18.02.2021). İstanbul ve İzmir illerinin seçim çevreleri sayısı değişmediği için bu illerin seçim çevreleri içerisinde yer alan ilçelerde bir değişikliğe gidilmedi.

66 Ankara ve Bursa'da seçim çevreleri sayısı arttığı için bu seçim çevrelerinin çıkaracağı milletvekili sayılarında düşüş meydana gelmiştir. 
maddesini konu edinmiş ve bu maddenin değiştirilişini, anayasa değişikliği teklifi kanunun madde gerekçeleri, TBMM Genel Kurulu'na sunulan Anayasa Komisyonu Raporları ve TBMM Genel Kurul görüşmeleri bağlamında ele almıştır. TBMM üye sayısı değişikliği ile ilgili Anayasa değişikliği teklifi kanunlarının madde gerekçeleri, Anayasa Komisyonu Raporları ve TBMM Genel Kurul görüşmeleri dikkate alındığında, ilk anayasa değişikliği teklifinin diğer ikisinden hem gerekçe olarak hem de mecliste bulunan partilerin bu değişiklik teklifine olan destekleri bakımından ayrıldığ edilebilir.

İkinci olarak ise, TBMM üye sayısı OECD üyesi ülkelerin millet meclisi üye sayıları ile Taagepera tarafından ortaya atılan küpkök yasası bağlamında mukayese edilmiştir. Bu mukayese göstermektedir ki, Türkiye'de ki milletvekili sayısı nüfusunun küpkökünün üzerinde olmasına rağmen üç defa artırılmıştır. Bununla berber, millet meclisi üye sayısı nüfusunun küpkökünün üzerinde olan OECD ülkelerinde ise millet meclisi üye sayısını azaltma yönünde bir eğilim söz konusudur.

Son olarak ise, milletvekili sayısının 550'den 600'e çıkarılmasına da değinilmiş ve bu durumun seçim çevresi sayısının $85^{\prime}$ ten $87^{\prime}$ e çıkmasına ve 37 seçim çevresinin milletvekili sayısının artmasına sebebiyet verdiği tespit edilmiştir.

Belirtmek gerekir ki, milletvekili sayısı artışı için anayasa değişikliği teklifi kanunu madde gerekçesinde, Anayasa Komisyonu Raporlarında ve TBMM Genel Kurulu'nda ileri sürülen sebeplerin, örneğin parti içi adaylık mücadelelerinde yumuşamasının yaşanması gibi, bu değişiklikler yoluyla sağlanıp sağlanamadığı başka araştırmalar tarafından konu edinilebilir.

\section{KAYNAKÇA}

AKÇA, Kürşat, "Türk Mevzuat ve Uygulaması Çerçevesinde Anayasa Değişikliği İçin TBMM'de Yapılan Oylamalar ve Bu Oylamalarda Aranan Karar Yeter Sayısı" Dicle Üniversitesi Hukuk Fakültesi Dergisi, Y11: 2017, Cilt: 22, Say1: 36, (s. 31-58)

ANAYURT, Ömer., Anayasa Hukuku Genel Kısım (Temel İlkeler, Kavram ve Kurumlar),

2. Basım, Seçkin Akademik ve Mesleki Yayınlar, Ankara, 2019. 
ARMAĞAN, Servet, "Türkiyede Parlamento Seçimleri”, İstanbul Üniversitesi Hukuk Fakültesi Mecmuası, Y11: 1967, Cilt: 33, Say1: 3-4, (s. 45-100).

BBC, Italians vote to slash size of parliament by a third, https://www.chicagomanualofstyle.org/tools citationguide/citation-guide-1.html\#cgwebsite, (erişim tarihi: 12.02.2021).

COAKLEY, John, "The Strange Revival of Bicameralism", The Journal of Legislative Studies, Y11: 2014, Cilt: 20, Say1: 4, (s. 542-572).

CONSEIL CONSTITUTIONNEL, Constitution of 4 October 1958, https://www.conseilconstitutionnel.fr/en/constitution-of-4-october-1958, (erişim tarihi: 25.01.2021).

FENDOĞLU, Hasan Tahsin., Anayasa Hukuku, 7. Basım, Yetkin Yayınları, Ankara, 2019.

FOLKETINGET THE DANISH PARLIAMENT, The Constitutional Act of Denmark, https://www.thedanishparliament.dk/en/democracy/the-constitutional-act-of-denmark. (erişim tarihi: 25.01.2021).

FRANCE24, Franch Government wants to scrap number of MPs by 25 percent, https://www.france24.com/en/20190829-french-government-wants-scrap-number-mps25-percent, (erişim tarihi: 12.02.2021).

FREDERICK, Brian, Congressional Representation and Constituents. The Case for increasing the US House of Representatives, Rothledge, New York, 2010.

GÖZLER, Kemal., Anayasa Hukukunun Genel Esasları Ders Kitabı, 11. Basım, Ekin Basım Yayın Dağıtım, Bursa, 2019.

HELLENIC PARLIAMENT, The Constitution of Greece, https://www.hellenicparliament.gr/en/Vouli-ton-Ellinon/To-Politevma/Syntagma/, (erişim tarihi: 7.02.2021).

IPU PARLINE, Global Data on National Parliaments, https://data.ipu.org/elections, (erişim tarihi: 17.02.2021).

İBA, Şeref., Anayasa Hukuku Genel Esaslar, 3. Basım, Turhan Kitabevi Yayınları, Ankara, 2017. 
JACOBS, Kristof / OTJES, Simon, "Explaining the Size of Assemblies. A Longitudinal Analysis of the Design and Reform of Assembly Size in Democracies around the World", Electoral Studies, Y11: 2015, Cilt: 40, (s. 280-292).

JOHNSTON, Ron / ROSSITER, David / PATTIE, Charles, "When is a Gerrymander Not a Gerrymander: Who Benefits and Who Loses from the Changed Rules for Defining Parliamentary Constituencies?”, The Political Quarterly, Y11: 2017, Cilt: 88, Say1: 2, (s. 211-220).

KABOĞLU, İbrahim Ö., Anayasa Hukuku Dersleri (Genel Esaslar), 14. Basım, Legal Yayıncılık, İstanbul, 2019.

LADEWIG, Jeffrey W / JASINSKI Mathew P, "On the Causes and Consequences of and Remedies for Interstate Malapportionment of the U.S. House of Representatives" Perspectives on Politics, Y11: 2008: Cilt: 6, Say1: 1, (s. 89-107).

LIJPHART, Arend, "Reforming the House: Three Moderately Radical Proposalss", PS: Political Science and Politics, Y11: 1998, Cilt: 31, Say1: 1, 1998, (s. 10-13).

MARGARITONDO, Giorgio, "Size of National Assemblies: The Classic Derivation of the CubeRoot Law is Conceptually Flawed" Frontiers in Physics, Y11: 2021, (s.1-4).

NIŞANCI, Şükrü / ÖZDEMİR, Abdulkadir, "Dünyada Uygulanan Seçim Sistemleri Işığında Türkiye için Alternatif Seçim Önerileri”, Atatürk Üniversitesi Sosyal Bilimler Enstitüsü Dergisi, Y11: 2017, Cilt: 21, Say1: 2, (s. 723-745).

NORTON, Philip, "The Individual Member in the British House od Commons: Facing both Ways and Marching Forward", The Journal of Legislative Studies, Y11: 1999, Cilt: 5, Say1: 34, (s. 53-74).

NUFUSU.COM, Türkiye Nüfusu, https://www.nufusu.com/, (erişim tarihi: 14.01.2021)

OECD, OECD accession candidades, https://www.oecd.org/about/members-and-partners/ (erişim tarihi: 15.02.2021).

OECD, Government at a Glance Contextual Factors, http://www.oecd.org/gov/governmentat-a-glance-2019-contextual-factors.pdf, (erişim tarihi: 24.01.2021), 
OLGUN, Kenan, “Türkiye’de Cumhuriyetin İlanından 1950’ye Genel Seçim Uygulamaları”, Atatürk Araştırma Merkezi Dergisi, Yı1: 2011, Cilt: 27, Sayı: 79, (s. 1-36).

ÖZBUDUN, Ergun, "Seçim Sistemleri ve Türkiye”, Ankara Üniversitesi Hukuk Fakültesi Dergisi, Y11: 1995, Cilt: 44, Say1: 1 (s. 521-539).

PARLIAMENT OF THE CZECH REPUBLIC CHAMBER OF DEPUTIES, Constitution of the

Czech Republic, https://www.psp.cz/en/docs/laws/1993/1.html (erişim tarihi: 25.01.2021).

RIIGI TEATAJA, The Constitution of the Republic of Estonia, RiigiTeataja, https://www.riigiteataja.ee/en/eli/521052015001/consolide (erişim tarihi: 25.01.2021).

SENADO DE ESPANA, https://www.senado.es/web/conocersenado/normas/constitucion/detalleconstitucioncompl eta/index.html?lang=en (erişim tarihi: 21.01.2021).

TAAGEPERA, Rein, , "The Size of National Assemblies”, Social Science Research, Y11; 1972, Cilt: 1, Say1: 4, (s. 385-401).

TEZİÇ, Erdoğan., Anayasa Hukuku, 23. Basım, Beta Basım Yayım Dağıtım, İstanbul, 2019.

TÜRKIYYE BÜYÜK MILLET MECLİSİ (TBMM), Türkiye Cumhuriyeti Anayasası, https://www.tbmm.gov.tr/anayasa.htm. (erişim tarihi: 14.02.2021).

TÜRKIYYE CUMHURIYETİ ANAYASA MAHKEMESİ (AYM), 1876 Kânûn-i Esâsî, https://www.anayasa.gov.tr/tr/mevzuat/onceki-anayasalar/1876-k\%C3\%A2n\%C3\%BBni-es\%C3\%A2s\%C3\%AE/. (erişim tarihi: 25.01.2021).

TÜRKIYE CUMHURIYETI ANAYASA MAHKEMESİ (AYM), 1961 Anayasası, https://www.anayasa.gov.tr/tr/mevzuat/onceki-anayasalar/1961-anayasasi// (erişim tarihi: 25.01.2021).

TÜRKIYE İSTATISTIIK KURUMU (TÜIK), Adrese Dayalı Nüfus Kayıt Sistemi Sonuçları”, https://data.tuik.gov.tr/Bulten/Index?p=Adrese-Dayali-Nufus-Kayit-Sistemi-Sonuclari2017-27587. (erişim tarihi: 08.02.2021). 
YSK, 24. Dönem Milletvekili Genel Seçimi, İllerin Çıkaracağı Milletvekili Sayıları, https://www.ysk.gov.tr/tr/12-haziran-2011-xxiv-donem-milletvekili-genel-secimi/4929, (erişim tarihi: 18.02.2021).

YÜKSEK SEÇIM KURULU, Şevreleri, https://www.ysk.gov.tr/doc/karar/dosya/77539/2018-263.pdf, (erişim tarihi: 06.02.2021). 